\section{Journal of Sciences and \\ Engineering}

Vol. 1, $\mathrm{N}^{\circ}$ 1, 2017

\title{
Contribution of a High School GLOBE - Peru to the report and verification of climate change
}

\author{
Jhonny Valverde Flores ${ }^{a, \text { * }}$ \\ a Institute of Sciences and Engineering, Centre of Research and Training to the Regional Development (CINCADER). \\ Lima 39, Peru. \\ ihoval1@yahoo.es
}

\section{Resumen}

El cambio climático es un cambio significativo y duradero de los patrones locales o globales del clima que actualmente está afectando a los diferentes componentes del planeta tierra. Los colegios GLOBE contribuyen a la educación ambiental en las instituciones educativas, incentivando a los alumnos a realizar investigación mediante los datos que ellos mismos generan para así poder contribuir a dar soluciones a los problemas asociados a fenómenos climáticos, al manejo de los recursos hídricos y a la gestión de la biodiversidad.

Palabras clave: Programa GLOBE, Cambio climático, Variables climáticas, colegios

\begin{abstract}
Climate change is a significant and lasting change of local or global climate patterns that is currently affecting the different components of planet earth. GLOBE schools contribute to environmental education in educational institutions, encouraging students to carry out research using the data they generate, in order to contribute to solve the problems associated with climatic phenomena, the management of water resources and the biodiversity management.
\end{abstract}

Keywords: GLOBE Program, Climate change, Climate variables, high schools.

\section{Introduction}

Climate change affects natural, social and economic systems. It generates shortages of nutritious food and clean water, and destroys ecosystems and safe living environments, which leads to malnutrition, poor health and migration; effects that make young people especially vulnerable. The impacts of climate change include, among others: the melting of glaciers, rising sea levels and an increase in the frequency of extreme weather events such as droughts, cyclones and heavy rains. Climate change, in addition to a direct impact on the environment, affects health, economy and various aspects of the population (MINAM, 2016). In Peru, hydrometeorological phenomena (droughts, heavy rains, floods, frosts, hailstorms) have increased more than sixfold from 1997 to 2006 and extreme climatic events such as mudslides, floods, frosts and the El Niño phenomenon are occurring with greater frequency and intensity. These cases show that climate change is not a foreign phenomenon, but influences the economy of the country and the life of each of its inhabitants. 
SE

Vol. 1, $\mathrm{N}^{\circ}$ 1, 2017
Journal of Sciences and Engineering

Copyright @ 2017, CINCADER.

ISSN 2523-9503

GLOBE Peru is an educational project that helps to develop scientific learning and raise awareness of the potential impacts of climate change from the observation and permanent measurement of the different elements of climate, a global science education program for primary and secondary education, promoted by international scientific institutions such as NASA (National Aeronautics and Space Administration) and NOAA (National Oceanic and Atmospheric Administration). It forms a unique worldwide network of professors, students and scientists working together to better understand the environmental changes that happen around us (Ministry of Agriculture, Food and Environment-Spain).

GLOBE Peru intends that the students in a simple way, with the installation of a small meteorological house, make daily measurements of temperature, humidity, rainfall, types of clouds, etc. contributing to a better knowledge of our climate (MINAM, 2016). The data collected are valuable inputs for conducting research on various environmental issues or phenomena that occur in our environment.

The educational institutions, that enter the data that they collect in their station, will have graphs and tables of all the measurements made, from the "The Globe program" page they will be able to see the data of any educational institution. "(MINAM, 2016) For Peru, GLOBE provides an interesting opportunity to link education with environmental information. Through this Program, students learn from their environment in an experiential way and generate information that helps decision-making for a better coexistence and quality of life in their environment. GLOBE Peru aims that the schools that implement the Program, can become small research centers and environmental monitoring that will strengthen the knowledge we have of the local reality and thus make an effective contribution to local environmental management (Globe Program, 2008).

\section{Materials and Methods}

The research work was of the basic type. The design was not experimental, Comparative Descriptive since the data reported by the GLOBE school will be compared with the SENAMHI data to verify its value and veracity. Currently there are approximately 50 High schools GLOBE registered and registered at the national level, according to the environment ministry of Peru actively participating in the generation and recording of data of the different components of the planet earth through observation and tools provided by the school itself. The data was obtained from the High School Maria Parado de Bellido (Globe) Climatic variables.

Maximum Temperature: It is the highest temperature recorded in a day, and it occurs between 2:00 p.m. and 4:00 p.m. (Dictionary of Meteorology, 2016).

Minimum Temperature: It is the lowest temperature recorded in a day, and can be observed in between 06:00 and 08:00 hours (Dictionary of Meteorology, 2016).

Humidity: "Humidity itself simply refers to the amount of water vapor in the air. (APCD, 2016).

Instruments

- SENAMHI data report for 2016.

- GLOBE school data report for 2016. 


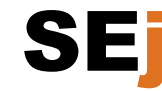

Vol. 1, $\mathrm{N}^{\circ}$ 1, 2017

\section{Journal of Sciences and Engineering}

Copyright @ 2017, CINCADER.

ISSN 2523-9503
A publication of

\section{CINCADER}

Centre of Research and Training for

Regional Development Online at www.journals.cincader.org

\section{Results}

\section{Description of results}

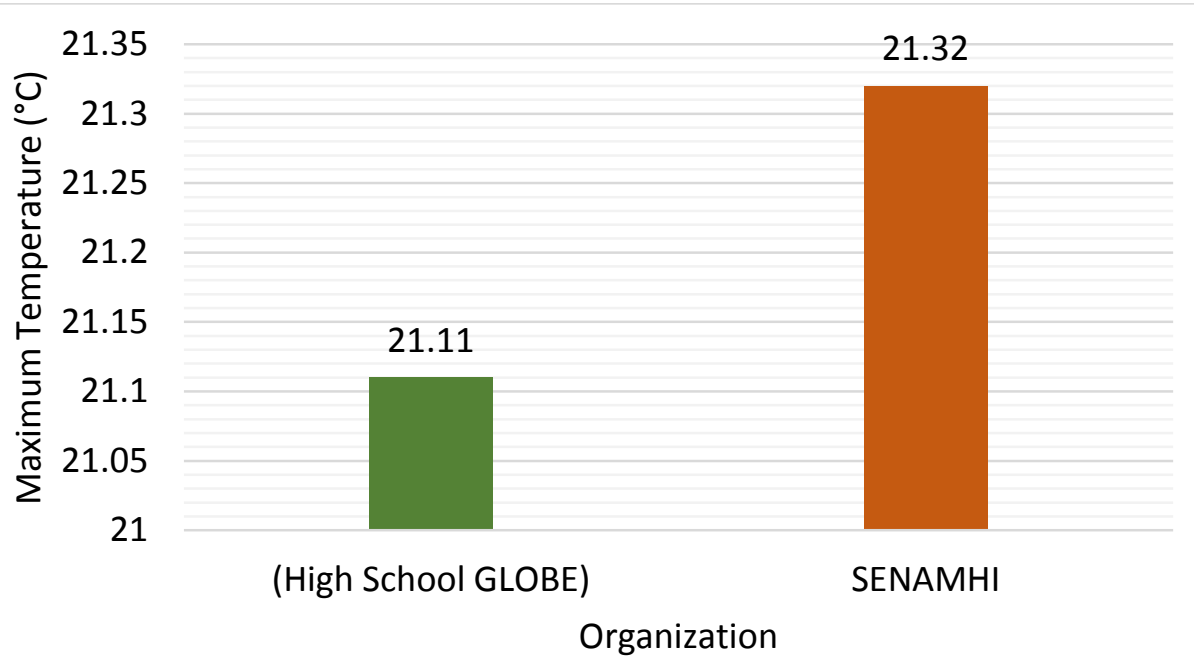

Figure 1. Maximum Temperature between High School GLOBE and SENAMHI. (Months May to August 2016).

The maximum temperature difference reported by the High School GLOBE and SENAMHI is observed. The measurement difference is $0.21^{\circ} \mathrm{C}$.

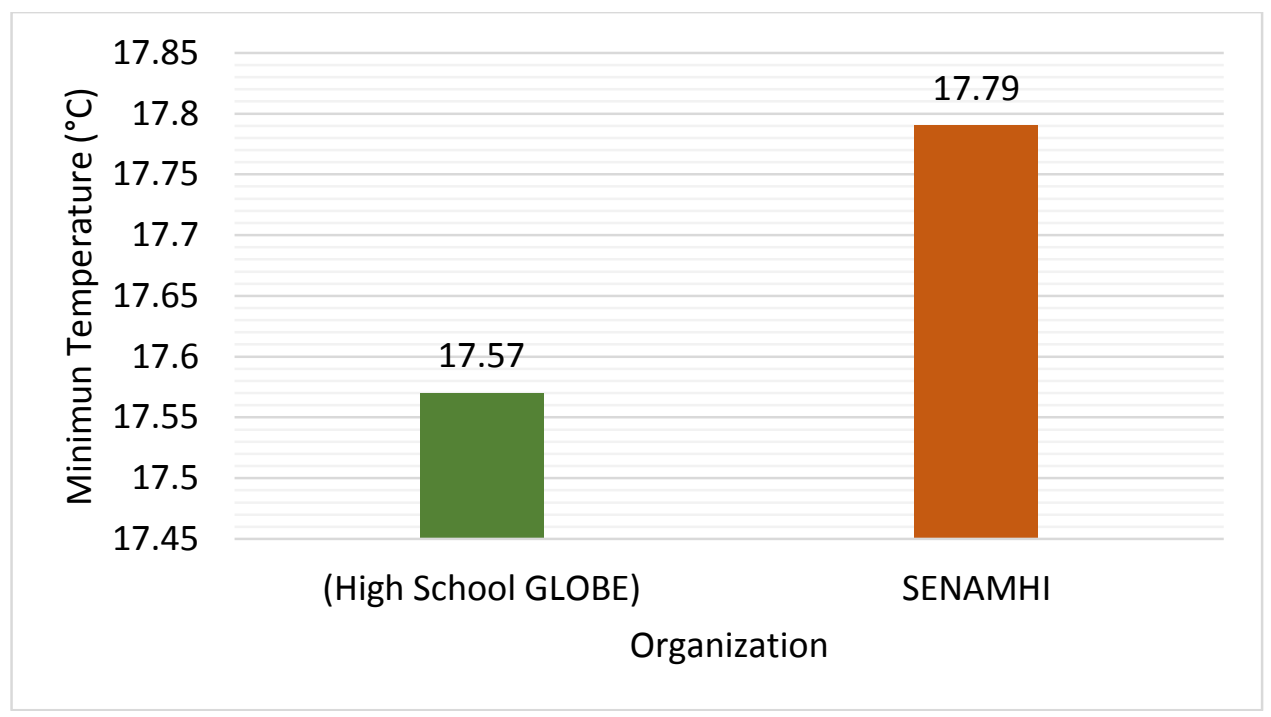

Figure 2. Minimum Temperature between High School GLOBE and SENAMHI.

(Months May to August 2016). 


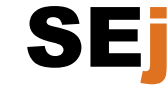

Vol. 1, $\mathrm{N}^{\circ}$ 1, 2017
Journal of Sciences and

Engineering

Copyright @ 2017, CINCADER.

ISSN 2523-9503

The minimum temperature difference reported by the educational institution GLOBE and SENAMHI is observed. The measurement difference is $0.22^{\circ} \mathrm{C}$.

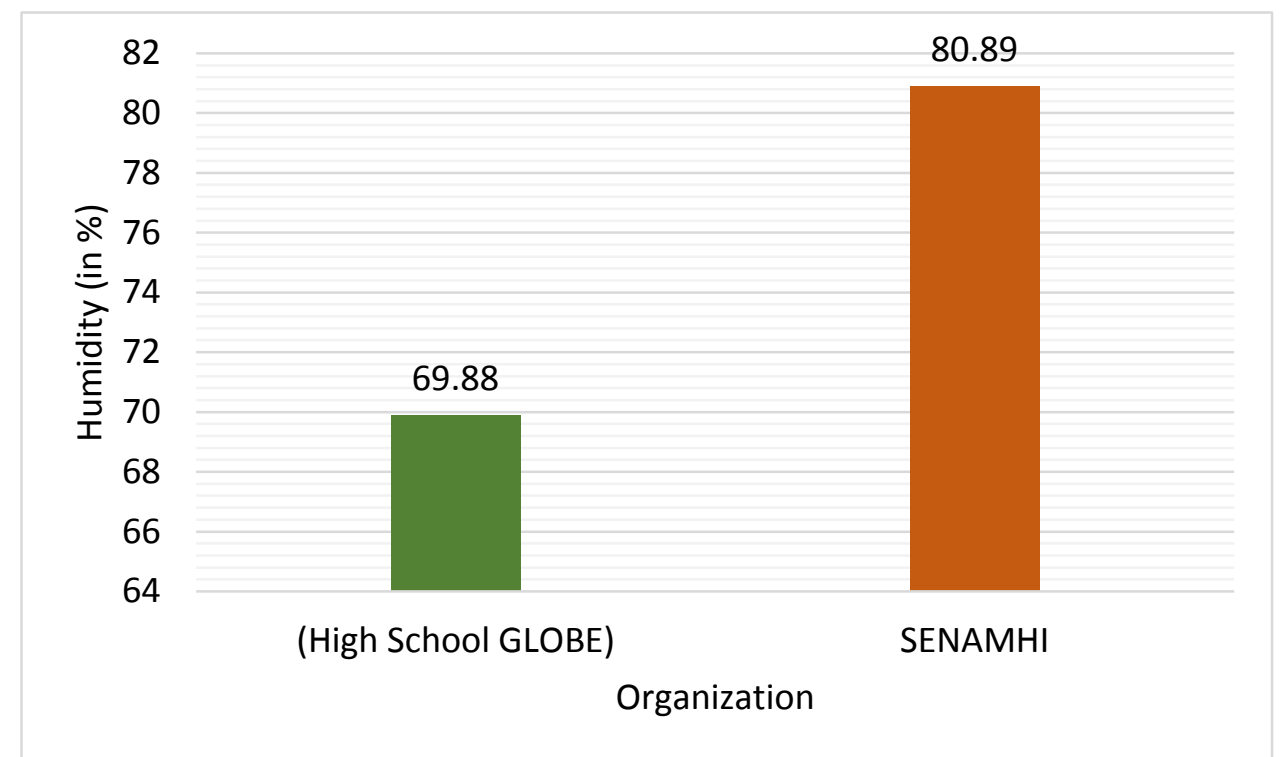

Figure 3. Humidity measured by High School GLOBE and SENAMHI.

(Months May to August 2016).

The difference in humidity reported by the educational institution GLOBE and SENAMHI is observed. The measurement difference amounts to $11.01 \%$.

\section{Conclusions}

- The observation and verification of the data obtained from the meteorological booth of the High School María Parado de Bellido show us that they are reliable data to carry out research and know the climatic variability that exists in these years.

- High School GLOBE works with the climatic variables such as Maximum temperature, minimum temperature, Humidity as well as observing the type and coverage of clouds.

- From the evaluation of the data obtained from the High School María Parado de Bellido del Rímac through the instruments has in the meteorological booth in school yard and the comparison of the data from SENAMHI, the High School GLOBE only verify data during the school days that are from Monday to Friday and verifies this data every day.

\section{Acknowledgments}

We gratefully acknowledge to the Institute of Science and Engineering, Centre of Research and Training to the Regional Development, (In Spanish, Centro de Investigacion y Capacitacion para el Desarrollo Regional-CINCADER) for allowing us to share technical experiences. 


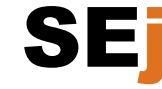

Vol. 1, No 1, 2017
Journal of Sciences and

Engineering

Copyright (C 2017, CINCADER.

ISSN 2523-9503
A publication of

\section{CINCADER}

Centre of Research and Training for

Regional Development

Online at www.journals.cincader.org

\section{Reference}

APCD-página web de servicios meteorológicos. Humedad: Informe.2016.30.nov.2016. <http://apcd-spv.org/index.php?lang=es\&secc=variables\&type=humitat>

Diccionario de meteorología. 2016.20. 30.noviembre.2016. <http://www.tutiempo.net/meteorologia/diccionario/temperatura-maxima.html>

Junta de Andalucía. Educación Ambiental y Cambio Climático [en línea]. Grandulfo impresores S.L, [2012] [fecha de consulta: 26 octubre 2016]. Disponible en: https://josechuferreras.files.wordpress.com/2012/01/guc3adadidc3a1ctica-ed-ambiental-y-cambio-climatico.pdf ISBN: 978-84-92807-68-0

MINAM. ¿Por qué el Perú es el tercer país más vulnerable al cambio climático?: Informe, Perú. 2016. 19.Oct.2016.

<http://www.minam.gob.pe/cambioclimatico/por-que-el-peru-es-el-tercer-pais-mas-

vulnerable-al-cambio-climatico/>

Program GLOBE. 2008.

http://www.minam.gob.pe/educacion/voluntariado/programa-globe-peru-conciencia-ambientaldesde-la-escuela/ 